\title{
Agrobacterium-Mediated Transformation and Insertional Mutagenesis in Colletotrichum acutatum for Investigating Varied Pathogenicity Lifestyles
}

\author{
Pedro Talhinhas $\cdot$ S. Muthumeenakshi • \\ João Neves-Martins · Helena Oliveira • \\ S. Sreenivasaprasad
}

(C) Humana Press Inc. 2008

\begin{abstract}
Colletotrichum acutatum is a cosmopolitan pathogen causing economically important diseases known as anthracnose on a wide range of hosts. This fungus exhibits varied pathogenicity lifestyles and the tools essential to understand the molecular mechanisms are still being developed. The transformation methods currently available for this species for gene discovery and functional analysis involve protoplast transformation and are laborious and inefficient. We have developed a protocol for efficient Agrobacterium tumefaciens-mediated transformation (ATMT) of C. acutatum. Using this protocol we were able to transform $C$. acutatum isolates belonging to different genetic groups and originating from different hosts. The transformation efficiency was up to 156 transformants per $10^{4}$ conidia, with $>70 \%$ transformants showing single location/single copy integration of T-DNA. Binary vector pBHt2-GFP was constructed, enabling green fluorescence protein tagging of $C$. acutatum strains, which will be a useful tool for epidemiology and histopathology studies. The ATMT protocol developed was used to identify putative pathogenicity mutants, suggesting the applicability of this technique for rapid generation of a large panel of insertional mutants of $C$. acutatum leading to the identification of the genes associated with the varied lifestyles.
\end{abstract}

Keywords Colletotrichum acutatum - Agrobacterium tumefaciens-mediated transformation · Hygromycin B

P. Talhinhas $(\bowtie) \cdot J$. Neves-Martins $\cdot$ H. Oliveira Instituto Superior de Agronomia - Technical University of Lisbon, Tapada da Ajuda, Lisboa 1349-017, Portugal e-mail: ptalhinhas@isa.utl.pt

P. Talhinhas · S. Muthumeenakshi · S. Sreenivasaprasad Warwick HRI, University of Warwick, Wellesbourne, Warwickshire CV35 9EF, UK resistance - Green fluorescent protein expression · Insertional mutagenesis · Pathogenicity mutants

\section{Introduction}

Colletotrichum acutatum has a worldwide distribution, causing diseases generally known as anthracnose on a wide range of hosts including woody and herbaceous crops, ornamentals, fruits and conifers. C. acutatum displays high levels of genotypic and phenotypic diversity and worldwide populations cluster into at least eight distinct molecular groups. C. acutatum populations show pathogenic variability and cross-infection potential in relation to a number of hosts. The pathogen has varied infection strategies and complex epidemiology, exhibiting pathogenic and non-pathogenic lifestyles on target hosts, nontarget crops and weeds [1, 2]. In view of the economic importance of the diseases caused by this pathogen on crops such as almond, citrus, olive and strawberry, in-depth studies on epidemiology and infection strategies have been carried out [3]. However, very little information is available on the molecular mechanisms regulating varied pathogenicity life styles and host preference and the basic tools required are only beginning to be developed by various groups. Horowitz and co-workers [4] transformed germinating conidia of a strawberry pathogenic isolate of C. acutatum by electroporation and selection on hygromycin, but only a maximum of six transformants could be obtained from $10^{7}$ conidia with $5 \mu \mathrm{g}$ of transforming DNA. Chung and co-workers [5] used the sulphonylurea (chlorimuron ethyl) selection system for the transformation of C. acutatum protoplasts with an acetolactate synthase gene (sur) cassette from Magnaporthe grisea. The transformation frequencies varied from 0 to 17.9 per $\mu \mathrm{g}$ DNA using 
$10^{7}$ protoplasts. In both these investigations neither REMI nor the use of homologous sequences increased the transformation efficiency [4, 5].

Agrobacterium tumefaciens-mediated transformation (ATMT) is a powerful tool for large-scale random mutagenesis, and efficiently targeted gene disruption, based on the transfer of the T-DNA into the recipient host genome (e.g. [6-8]). This technique has been shown to be applicable to yeasts [9] as well as filamentous fungi [10]. More recently, the potential of ATMT as a genetic analysis tool in functionally diverse fungi has been demonstrated [11-13] for green fluorescence protein (GFP) expression $[14,15]$, homologous gene replacement [16-18] and tagged mutagenesis $[19,20]$.

In this article, we describe an ATMT protocol for the efficient transformation of $C$. acutatum and GFP expression, overcoming the difficulties and low efficiencies previously reported $[4,5]$. We also characterised the type of T-DNA integrations in the fungal genome, and tested the potential application of this method for insertional mutagenesis to generate pathogenicity mutants to aid in future gene discovery studies.

\section{Materials and Methods}

Fungal Isolates, Bacterial Strains and Culture Conditions

Colletotrichum acutatum isolate CA397, a strawberry pathogen belonging to group A2 [1, 21], was grown on Potato Dextrose Agar (PDA, Sigma-Aldrich, UK) at $25^{\circ} \mathrm{C}$. Isolates PT29 (from white lupin), PT108, PT169 and PT227 (from olive) and CR46 (from grapevine) belonging to $C$. acutatum $[1,22,23]$ used in transformation experiments were grown under similar conditions. Sensitivity of C. acutatum to hygromycin and sulphonylurea [5] was tested in plate assays using isolate 397. PDA plates containing varying concentrations of hygromycin dissolved in water $(0,50,150,250$ and $375 \mu \mathrm{g} / \mathrm{ml})$ and sulphonylurea dissolved in dimethylformamide $(0,10,30,50$ and $75 \mu \mathrm{g} /$ $\mathrm{ml}$ ) were inoculated centrally with a $3 \mathrm{~mm}$ inoculum plug and the radial growth of the colony was measured after 8 days. Conidial suspensions were prepared from 5-day PDA cultures by adding ca. $5 \mathrm{ml}$ sterile distilled water to the plates, releasing spores and mycelium with a sterile loop and filtering through a sterile $200 \mu \mathrm{m}$ glass filter. Number of conidia in the suspension was counted using a haemocytometer and adjusted to required concentrations. Agrobacterium tumefaciens strain AGL1 (A. Soares) was grown on LB agar plates supplemented with $20 \mu \mathrm{g} / \mathrm{ml}$ rifampicin (Sigma-Aldrich) and $75 \mu \mathrm{g} / \mathrm{ml}$ carbenicillin (Sigma-Aldrich) at $26^{\circ} \mathrm{C}$ for 2 days. AGL1 containing a binary vector was grown on LB agar plates supplemented with $20 \mu \mathrm{g} / \mathrm{ml}$ rifampicin and $50 \mu \mathrm{g} / \mathrm{ml}$ kanamycin (Sigma-Aldrich) at $26^{\circ} \mathrm{C}$ for 2 days. Binary vector pBHt2 [24], based on pCAMBIA 1300 (AF234296; Cambia, Australia) containing the hygromycin B resistance (hph) gene under the Aspergillus nidulans trpC promoter (S. Kang) was transformed into Escherichia coli TOP 10 cells (TOPO TA cloning kit, Invitrogen, UK). The new cell line was grown on LB medium supplemented with $50 \mu \mathrm{g} / \mathrm{ml}$ kanamycin at $37^{\circ} \mathrm{C}$. Plasmid pPgpd/GFP010 [25], containing the $g f p$ cassette with the A. nidulans gpdA promoter and $\operatorname{trp} C$ terminator (A. Soares) was transformed into TOP 10 cells. The new cell line was grown on LB medium supplemented with $100 \mu \mathrm{g} / \mathrm{ml}$ ampicillin at $37^{\circ} \mathrm{C}$.

Binary Vector Construction and Transformation into Agrobacterium tumefaciens

A 2366-bp SacI and XbaI (Roche Diagnostics, Germany) digested fragment of pPgpd/GFP010 containing the $g f p$ cassette was isolated by gel purification using the QIAquick gel extraction kit (Qiagen, UK). SacI and XbaI digested and dephosphorylated (shrimp alkaline phosphatase; Roche Diagnostics) pBHt2 was prepared using the QIAquick PCR Purification kit. Digested pBHt2 and the pPgpd/GFP010 fragment were ligated using T4 DNA ligase (Roche Diagnostics). The 2366-bp fragment was cloned into the $S a c I$ and $X b a I$ sites within the multiple cloning site region of $\mathrm{pBHt} 2$, in opposite direction to that of the $h p h$ gene cassette to construct pBHt2-GFP (Fig. 1). pBHt2-GFP was transformed into TOP $10 \mathrm{E}$. coli cells. Correct orientation of pBHt2-GFP was confirmed by restriction mapping with HindIII, SacI and $X b a I$ and also by PCR verification of the $g f p$ and $h p h$ (described in " $P C R$ Confirmation of hph or gfp Gene in the Transformants”). All plasmid isolations were performed using the Plasmid Mini Kit (Qiagen).

For preparing the A. tumefaciens competent cells, AGL1 strain was grown in liquid $\mathrm{LB}$ to an $\mathrm{OD}_{660}$ of 0.15 . Cells were harvested by centrifugation $\left(5000 \mathrm{rpm} 10 \mathrm{~min} 4^{\circ} \mathrm{C}\right)$, washed thrice in $10 \mathrm{ml}$ chilled $100 \mathrm{mM}$ HEPES and once in $10 \%$ glycerol by centrifugation $5000 \mathrm{rpm} 10 \mathrm{~min} 4^{\circ} \mathrm{C}$ between each wash. The cells were resuspended in $1 \mathrm{ml}$ $10 \%$ glycerol for electroporation (alternatively, for chemically competent cells, resuspension was in $1 \mathrm{ml}$ of $20 \mathrm{mM}$ $\left.\mathrm{CaCl}_{2}\right)$. Competent cells $(40 \mu \mathrm{L})$ were mixed with $200 \mathrm{ng}$ plasmid (either pBHt2 or pBHt2-GFP) and added to a prechilled electroporation cuvette. Electroporation was carried out by applying $2.5 \mathrm{kV}$ (at $400 \Omega$ ) with capacitance set at $25 \mu \mathrm{F}$ (Gene Pulser and Pulse Controller, Biorad, UK). Alternatively, $100 \mu \mathrm{l}$ of chemically competent cells were mixed with $1 \mu \mathrm{g}$ plasmid DNA, frozen in liquid nitrogen 


\begin{tabular}{|c|c|c|c|}
\hline $\begin{array}{c}\text { Co- } \\
\text { cultivation } \\
\text { medium }\end{array}$ & $\begin{array}{l}\text { Binary } \\
\text { vector }\end{array}$ & $\begin{array}{c}\text { No. of } \\
\text { conidia per } \\
\text { membrane }\end{array}$ & $\begin{array}{c}\text { Mean no. of } \\
\text { transformants } \\
\text { per } \\
\text { membrane }\end{array}$ \\
\hline \multirow{8}{*}{ IMAS } & \multirow{4}{*}{ pBHt2 } & $10^{3}$ & 0.29 \\
\hline & & $5 \times 10^{3}$ & 29.63 \\
\hline & & $10^{4}$ & 156.29 \\
\hline & & $\begin{array}{c}5 \times 10^{4} \\
10^{5}\end{array}$ & Countless \\
\hline & \multirow{4}{*}{$\begin{array}{c}\text { pBHt2- } \\
\text { GFP }\end{array}$} & $10^{3}$ & 0.00 \\
\hline & & $5 \times 10^{3}$ & 17.85 \\
\hline & & $10^{4}$ & 44.88 \\
\hline & & $\begin{array}{c}5 \times 10^{4} \\
10^{5}\end{array}$ & Countless \\
\hline \multirow{8}{*}{ IM } & \multirow{4}{*}{ pBHt2 } & $10^{3}$ & 0.44 \\
\hline & & $5 \times 10^{3}$ & 60.19 \\
\hline & & $10^{4}$ & 129.71 \\
\hline & & $\begin{array}{c}5 \times 10^{4} \\
10^{5}\end{array}$ & Countless \\
\hline & \multirow{4}{*}{$\begin{array}{c}\text { pBHt2- } \\
\text { GFP }\end{array}$} & $10^{3}$ & 2.24 \\
\hline & & $5 \times 10^{3}$ & 32.13 \\
\hline & & $10^{4}$ & 81.90 \\
\hline & & $\begin{array}{c}5 \times 10^{4} \\
10^{5}\end{array}$ & Countless \\
\hline
\end{tabular}

Fig. 1 Left (table)-Number of Colletotrichum acutatum transformants obtained (discrete colonies growing on the selection medium and confirmed by subsequent subculturing; average of six transformation experiments) in relation to the number of conidia, the binary vector used (pBHt2 or $\mathrm{pBHt} 2-\mathrm{GFP})$ and the presence (IMAS) or absence (IM) of acetosyringone $(200 \mu \mathrm{M})$ in the co-cultivation medium (countless-coalescent colonies/continuous mycelial mat). Right (a) - Map of binary vector $\mathrm{pBHt} 2$-GFP, obtained by cloning the green fluorescence protein gene, gfp (including A. nidulans gpdA promoter and $\operatorname{trpC}$ terminator; [25]), into the $S a c \mathrm{I} / \mathrm{Xba \textrm {I }}$ sites within the multiple cloning site region of pBHt2 [26]; T-DNA, including the $g f p$ and $h p h$ (hygromycin B resistance) genes defined by the left

for $5 \mathrm{~min}$ and incubated at $37^{\circ} \mathrm{C}$ for $35 \mathrm{~min}$. After transformation, cells were immediately recovered by adding $1 \mathrm{ml} \mathrm{LB}$ and incubated for $3 \mathrm{~h}$ at $26^{\circ} \mathrm{C} 150 \mathrm{rpm}$. Cells were plated in LB agar plates supplemented with $20 \mu \mathrm{g} / \mathrm{ml}$ rifampicin and $50 \mu \mathrm{g} / \mathrm{ml}$ kanamycin at $26^{\circ} \mathrm{C}$ for 2 days. Selected colonies were subcultured and the new cell lines were stored at $-80^{\circ} \mathrm{C}$.

\section{Agrobacterium tumefaciens-Mediated Transformation and GFP Expression}

AGL1 cell line containing either pBHt2 or pBHt2-GFP recovered from $-80^{\circ} \mathrm{C}$ storage was first grown on $\mathrm{LB}$ plates containing $30 \mu \mathrm{g} / \mathrm{ml}$ kanamycin and $20 \mu \mathrm{g} / \mathrm{ml}$ rifampicin at $26^{\circ} \mathrm{C}$ for 2 days. A single colony was

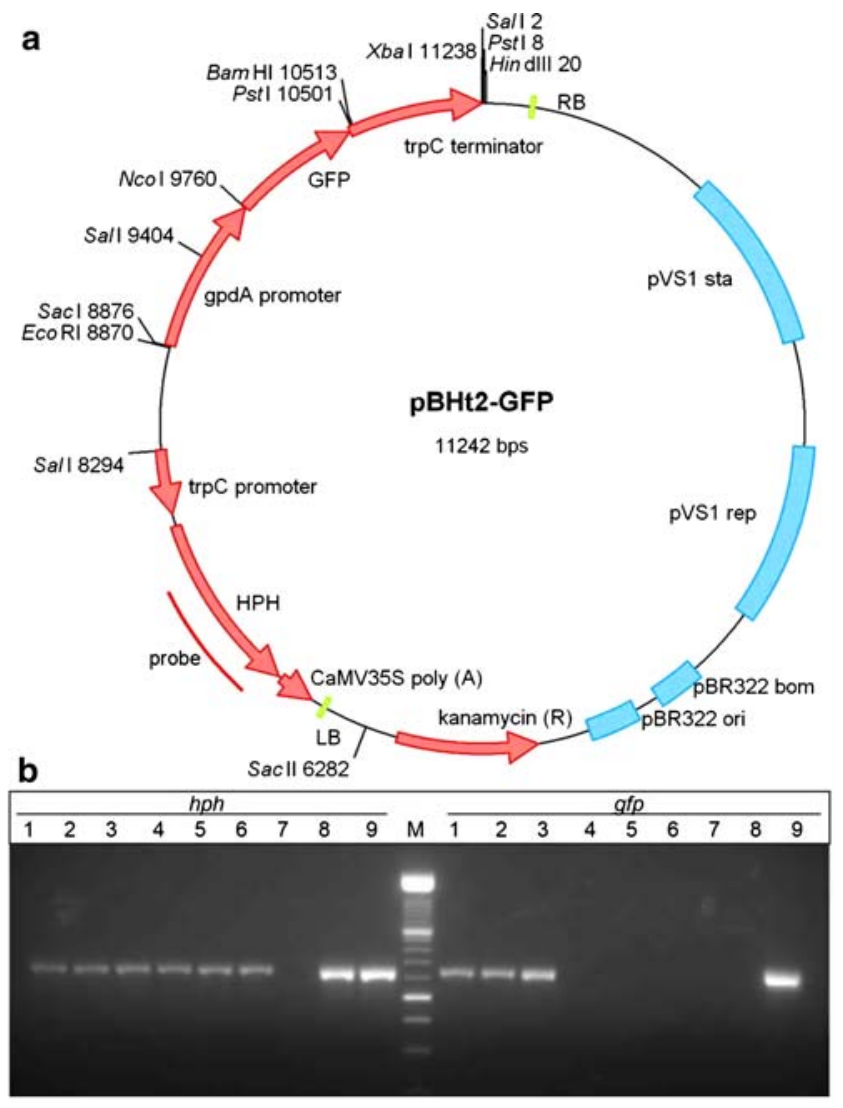

border (LB) and the right border (RB); probe (as used for Southern analysis) region marked. Right (b)-Fragments amplified by PCR using the $h p h$ (left panel) or $g f p$ (right panel) specific primers with DNA from six $C$. acutatum transformants obtained with AGL1 containing binary vectors pBHt2-GFP (lines 1-3) or pBHt2 (lines 46); M-marker XIV (Roche Diagnostics; bright bands are $2642 \mathrm{bp}$, $1000 \mathrm{bp}$ and $500 \mathrm{bp}$ ); Lane 7: CA397-wild type (negative control); Lane 8: pBHt2 - containing hph gene (positive control for PCR with $h p h$-specific primers) but not $g f p$ (negative control for PCR with $g f p$-specific primers); Lane 9: pBHt2-GFP_containing both $h p h$ and $g f p$ (positive control for both PCRs)

transferred to LB medium amended with $30 \mu \mathrm{g} / \mathrm{ml}$ kanamycin and grown overnight at $26^{\circ} \mathrm{C}$. Subsequently, $2 \mathrm{ml}$ of the cells were used to inoculate a $25 \mathrm{ml}$ culture grown overnight at $26^{\circ} \mathrm{C}$ and $150 \mathrm{rpm}$ in minimal medium (MM). The composition of $\mathrm{MM}$ was $11.8 \mathrm{mM} \mathrm{K}_{2} \mathrm{HPO}_{4}+10.7$ $\mathrm{mM} \mathrm{KH} \mathrm{PO}_{4}, \mathrm{pH} 7.0 ; 2.0 \mathrm{mM} \mathrm{MgSO} \mathrm{Mg}_{4} .7 \mathrm{H}_{2} \mathrm{O} ; 2.6 \mathrm{mM}$ $\mathrm{NaCl} ; 456.4 \mu \mathrm{M} \mathrm{CaCl} 2.2 \mathrm{H}_{2} \mathrm{O} ; 10.1 \mathrm{mM}$ glucose; $9 \mu \mathrm{M}$ $\mathrm{FeSO}_{4} .7 \mathrm{H}_{2} \mathrm{O}$ and $3.8 \mathrm{mM}\left(\mathrm{NH}_{4}\right)_{2} \mathrm{SO}_{4}$ (adapted from [27, 28]). Optical density $\left(\mathrm{OD}_{660}\right)$ of the cell suspension was recorded at $660 \mathrm{~nm}$ and an appropriate volume was used to prepare $50 \mathrm{ml}$ of the suspension at $0.15 \mathrm{OD}_{660}$ in the induction medium (IM). The composition of IM was same as $\mathrm{MM}$, with the following modifications: $40 \mathrm{mM} 2-(\mathrm{N}-$ Morpholino)-ethanesulphonic acid, $\mathrm{pH} 5.3$ and $0.5 \%$ glycerol (adapted from [9, 28]). Cells from $20 \mathrm{ml}$ of the suspension in IM were pelleted by centrifugation for $8 \mathrm{~min}$ 
at $2500 \mathrm{rpm}$ and resuspended in $50 \mathrm{ml}$ IM containing $30 \mu \mathrm{g} / \mathrm{ml}$ kanamycin and $200 \mu \mathrm{M}$ acetosyringone $\left(3^{\prime}, 5^{\prime}\right.$ Dimethoxy-4'-hydroxyacetophenone, Acros, Belgium). A freshly prepared stock of acetosyringone $(100 \mathrm{mM}$ in ethanol) was used. Cells were incubated for $6 \mathrm{~h}$ at $26^{\circ} \mathrm{C}$ and $150 \mathrm{rpm}$. Petri plates $(9 \mathrm{~cm}$ diam.) containing IM or IMAS (IM amended with $200 \mu \mathrm{M}$ acetosyringone) with $2 \%$ agar and overlaid with a cellophane membrane were used to spread a $C$. acutatum isolate conidial suspension $(100 \mu \mathrm{l})$ together with an identical volume of A. tumefaciens cell suspension. Different concentrations of the conidial suspension were tested (ranging from $10^{3}$ to $10^{6}$ conidia per plate), while the volume of bacterial suspension was kept constant [29]. Co-cultivation plates were routinely incubated for $48 \mathrm{~h}$ at $22^{\circ} \mathrm{C}$, although 20 and $25^{\circ} \mathrm{C}$ were also tested. The membranes were then removed, cut into six to eight pieces and placed on a selective medium of PDA amended with $250 \mu \mathrm{g} / \mathrm{ml}$ hygromycin (Invivogen, USA) and $400 \mu \mathrm{g} / \mathrm{ml}$ cefotaxime (Duchefa, Netherlands). Fungal colonies growing on the selective medium were transferred to $\mathrm{PDA}_{\mathrm{hyg}, \mathrm{cf}}$ or $\mathrm{YEG}_{\mathrm{hyg}, \mathrm{cf}}$ (a liquid medium containing $56 \mathrm{mM}$ glucose and $0.2 \%$ yeast extract, amended with the same antibiotics). Transformants were maintained on

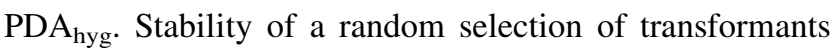
was tested by subculturing at least thrice on PDA without the selective antibiotic and then checking their capacity to grow on $\mathrm{PDA}_{\text {hyg. }}$ A $C$. acutatum conidial sample not co-cultured with A. tumefaciens cells but handled as described above throughout the selection procedure served as negative control.

GFP expression in the transformants obtained with AGL1-pBHt2-GFP was assessed by epifluorescence microscopy. Actively growing hyphae from $\mathrm{PDA}_{\text {hyg }}$ or $\mathrm{YEG}_{\text {hyg }}$ cultures were observed under ultraviolet light (350-400 nm) on an Olympus IX70 microscope at 400× magnification. Wildtype isolate was used as control.

\section{Isolation of Genomic DNA from Putative}

Transformants

To extract DNA for PCR assays, transformants were grown on $\mathrm{PDA}_{\text {hyg }}$ or $\mathrm{YEG}_{\text {hyg }}$ liquid without agitation. A small amount of mycelium (approx. 2-mm diameter clump) was resupended in $1 \mathrm{ml} 1 \mathrm{mM}$ Tris- $\mathrm{HCl}$ containing $100 \mu \mathrm{m}$ glass beads and 3\% (w/v) Chelex 100 (Sigma-Aldrich) and vortexed for $1 \mathrm{~min}$. The suspension was subjected to three freeze-boil cycles of $1 \mathrm{~min}$ each in liquid nitrogen and boiling water, with a final 5 min boiling. This was followed by vortexing for $1 \mathrm{~min}$ and incubation for $40 \mathrm{~min}$ at $55^{\circ} \mathrm{C}$. The mix was centrifuged $5 \mathrm{~min}$ at $13000 \mathrm{rpm}$ and the top $100 \mu \mathrm{l}$ recovered and stored at $-20^{\circ} \mathrm{C}$. To extract DNA for Southern analysis, transformants were grown in $30 \mathrm{ml}$ of
$\mathrm{YEG}_{\text {hyg }}$ at $25^{\circ} \mathrm{C}$ for $3-5$ days. Mycelium was filtered through sterile filter paper in a Buchner funnel, frozen in liquid nitrogen, freeze-dried and grounded to a fine powder. DNA extraction was performed using $10 \mathrm{mg}$ of mycelial powder using GenElute Plant Genomic DNA Miniprep Kit (Sigma-Aldrich) following manufacturer's instructions. DNA obtained in $200 \mu \mathrm{l}$ elution buffer was further concentrated by ethanol precipitation and resuspended in $20 \mu \mathrm{l}$ water.

PCR Confirmation of $h p h$ or $g f p$ Gene in the Transformants

Primers HPHF $-5^{\prime}$ cgatcttagccagacgagcg $3^{\prime}$ and HPHR$5^{\prime}$ ttgccctcggacgagtgctg $3^{\prime}$ derived from GenBank sequence (L76273) were used to amplify a $643 \mathrm{bp} h p h$ fragment. Primers eGFP361-5' ggccacaagttcagcgtgtc $3^{\prime}$ and eGFP998- $5^{\prime}$ agctcgtccatgecgagagt $3^{\prime}$ [30] were used to amplify a 638 bp $g f p$ fragment. PCR was performed with $5 \mu \mathrm{l}$ DNA, $1 \mu \mathrm{M}$ each primer (final concentration) and REDTaq ReadyMix PCR Mix (Sigma-Aldrich) in a final volume of $25 \mu \mathrm{l}$ on a Proteus II (Helena Biosciences, UK) thermalcycler. PCR programme included one cycle of $5 \mathrm{~min}$ at $94^{\circ} \mathrm{C}, 30$ cycles of $45 \mathrm{~s}$ at $94^{\circ} \mathrm{C}, 30 \mathrm{~s}$ at $55^{\circ} \mathrm{C}$ (for both $h p h$ and $g f p$ ) and $1 \mathrm{~min}$ at $72^{\circ} \mathrm{C}$ and a final cycle of 5 min at $72^{\circ} \mathrm{C}$.

\section{Southern Analysis of T-DNA Integration} in the Transformants

DNA samples $(1 \mu \mathrm{g})$ from a random selection of transformants were digested with either BglII (Roche Diagnostics) or HindIII (Invitrogen), overnight at $37^{\circ} \mathrm{C}$ using $10 \mathrm{U}$ of the enzyme and the appropriate buffer in a $20 \mu \mathrm{l}$ reaction. Restriction fragments were separated by agarose $(0.8 \%)$ gel electrophoresis overnight (ca. $20 \mathrm{~h}$ ) at $0.67 \mathrm{~V} / \mathrm{cm}$, along with DIG-labelled marker II (Roche Diagnostics). The $643 \mathrm{bp}$ fragment of the $h p h$ gene (200 pg) loaded on the gel $2 \mathrm{~h}$ before the end of electrophoresis served as positive hybridisation control. DNA was transferred to positively charged nylon membrane (Roche Diagnostics) following the standard Southern blotting protocol [31]. After blotting, the membrane was washed in $6 \times$ SSC for 2 min and the DNA was fixed by incubation at $80^{\circ} \mathrm{C}$ for $1 \mathrm{~h}$ and UV cross-linking at $0.35 \mathrm{~J} / \mathrm{cm}^{2}$. The blots were rinsed in hybridisation solution $(5 \times \mathrm{SSC}+$ $0.1 \% \mathrm{v} / \mathrm{v}$ Sarkosyl $+0.02 \%$ SDS) and then twice incubated for $1 \mathrm{~h}$ at $65^{\circ} \mathrm{C}$ in pre-warmed pre-hybridisation solution (hybridisation solution $+2 \% \mathrm{w} / \mathrm{v}$ casein blocking agent) in a rotating cylinder (Techne Hybridiser, UK). The $643 \mathrm{bp} \mathrm{hph}$ gene fragment was labelled with digoxigenin using PCR DIG Probe synthesis kit (Roche Diagnostics), 
gel checked and purified and was used as a probe. Salmon sperm DNA ( $200 \mu \mathrm{l}$ of $10 \mathrm{mg} / \mathrm{ml}$ stock; Sigma-Aldrich) was added to $200 \mathrm{ng}$ of the DIG-labelled $h p h$ probe. The probe mixture was denatured and mixed with a minimal volume of pre-warmed pre-hybridisation solution $(10 \mathrm{ml}$ for a $20 \times 20 \mathrm{~cm}$ membrane) and added to the membrane and incubated overnight at $65^{\circ} \mathrm{C}$. The membrane was washed twice with $3 \times \mathrm{SSC}+0.1 \%$ SDS (first wash at room temperature for $5 \mathrm{~min}$ and second at $65^{\circ} \mathrm{C}$ for $15 \mathrm{~min}$ ), twice with $1 \times \mathrm{SSC}+0.1 \% \mathrm{SDS}$ for $15 \mathrm{~min}$ at $65^{\circ} \mathrm{C}$ and twice with $0.2 \times \mathrm{SSC}+0.1 \%$ SDS for $15 \mathrm{~min}$ at $65^{\circ} \mathrm{C}$. For chemiluminescent detection, the membrane was first washed at room temperature on a platform shaker with $100 \mathrm{mM}$ Tris $\mathrm{HCl} \mathrm{pH} 7.5+150 \mathrm{mM} \mathrm{NaCl}$ for $5 \mathrm{~min}$, then with $100 \mathrm{mM}$ Tris $\mathrm{HCl} \mathrm{pH} 7.5+150 \mathrm{mM} \mathrm{NaCl}+$ $2 \%$ casein blocking agent for $30 \mathrm{~min}$ and finally with an identical solution containing Anti-Digoxigenin-AP Fab Fragments (1:5000 dilution; Roche Diagnostics) for 30 min. Following this, the membrane was washed twice with $100 \mathrm{mM}$ Tris $\mathrm{HCl} \mathrm{pH} 7.5+150 \mathrm{mM} \mathrm{NaCl}$ to remove any unbound antibody conjugate, once with $100 \mathrm{mM}$ Tris $\mathrm{HCl} \mathrm{pH} 9.5+100 \mathrm{mM} \mathrm{NaCl}+50 \mathrm{mM} \mathrm{MgCl}_{2}$ and finally with $20 \mathrm{ml}$ of previous solution containing $200 \mu \mathrm{l} \mathrm{CDP-}$ star (Roche Diagnostics) for the detection of nucleic acids. Membrane wrapped in cling film was used for autoradiography with 2-10 min exposure times.

\section{Pathogenicity Assay of Insertional Mutants}

Transformants were grown on $\mathrm{PDA}_{\text {hyg }}$ and inoculated on green 'Golden Delicious' apples which were previously surface-disinfected with $\mathrm{NaClO} 0.05 \%$ and rinsed in distilled water. The fruits were inoculated by making an approximately $0.8 \mathrm{~cm}$-deep hole using a cork borer and placing a $0.5 \mathrm{~cm}$ diameter plug of actively growing culture of the transformants. Fruits inoculated with the wildtype isolate CA397, and isolate AC58, originally obtained from apples with anthracnose symptoms and also an uncultured PDA plug, served as controls. Fruits were incubated for 13 days at $25^{\circ} \mathrm{C}$ under $100 \%$ relative humidity. The reactions were recorded as lesion type and diameter $(\mathrm{mm})$, production of mycelia and sporulation. Based on these data, an overall disease severity score (ranging from 0 to 10) was assigned. In a first screen, each transformant was inoculated once, with six inoculation spots per apple. In the second screen, each of the transformants exhibiting distinctive differences in pathogenicity plus appropriate controls were inoculated in four replicates, at four inoculation spots per apple, in a totally randomised design. For pathogenicity bioassays with strawberry, immature fruits (green-white stage) of 'Camarosa' variety were used. Wild type isolate CA397 and insertional mutants 1417 and 1577 were each inoculated on to 10 strawberries. Surface-disinfected fruits were inoculated with $10 \mu \mathrm{l}$ of a conidial suspension $\left(10^{6}\right.$ spores $\left./ \mathrm{ml}\right)$ and incubated under the conditions described above.

\section{Results and Discussion}

Co-cultivation of $C$. acutatum conidia with A. tumefaciens strain AGL1 containing a binary vector $\mathrm{pBHt} 2$ or $\mathrm{pBHt} 2-$ GFP consistently yielded high frequency of transformants in more than five independent experiments. A. tumefaciens strain AGL1 was used in this study, as it has been found to be more efficient than strains such as EHA105 and LBA1126 in ATMT of both asco- and basidio-mycete fungal species [32, 33]. C. acutatum isolates from citrus were considered moderately tolerant to selection agents such as hygromycin, bialaphos, benomyl and geneticin/ G418 [5]. In our tests, C. acutatum isolate 397 also showed tolerance to hygromycin at concentrations used routinely with other fungal species, and only at $250 \mu \mathrm{g} / \mathrm{ml}$ and above the growth was completely inhibited (Fig. 2). Tests with sulphonylurea also revealed that C. acutatum isolate 397 had high tolerance to this agent up to $75 \mu \mathrm{g} / \mathrm{ml}$ (data not shown). Consequently, in this study, hygromycin was used at a higher concentration $(250 \mu \mathrm{g} / \mathrm{ml})$ than that commonly used $(100 \mu \mathrm{g} / \mathrm{ml})$ with other fungi (e.g. [20, 34]). Similarly, in a recent study reporting a high-throughput ATMT system for insertional mutagenesis in Magnaporthe oryzae, $350 \mu \mathrm{g} / \mathrm{ml}$ of hygromycin was used [35]. After $48 \mathrm{~h}$ co-cultivation of $C$. acutatum conidia and AGL1 cells containing a binary vector and prior to transfer to the selection medium, a slight mycelial mat was visible covering the cellophane disc, corresponding to $48 \mathrm{~h}$ fungal growth on control plates. However, upon transfer of the discs to selection medium containing hygromycin at $250 \mu \mathrm{g} / \mathrm{ml}$, discrete colonies of transformants started appearing after 4 days. At lower hygromycin concentrations tested, it was

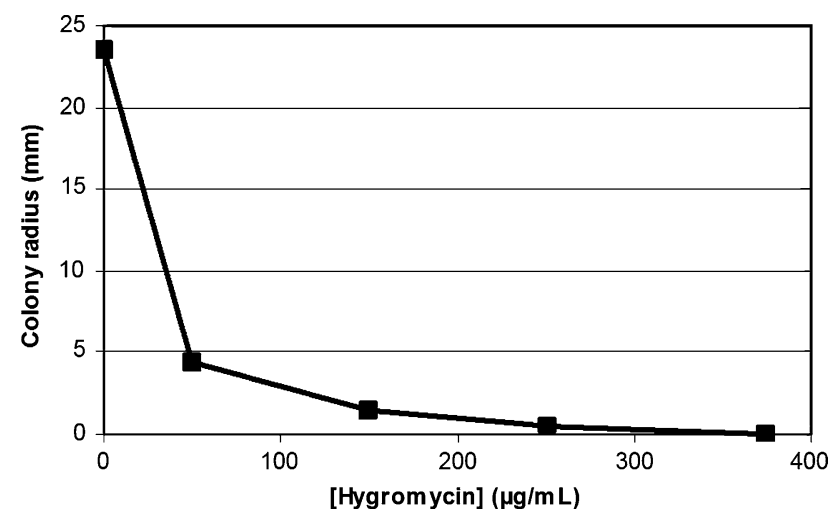

Fig. 2 Growth curve showing the sensitivity of Colletotrichum acutatum isolate 397 to various concentrations of hygromycin 
difficult to distinguish transformed colonies from the background growth (data not shown).

In various ascomycete fungi, $10^{6}$ conidia have been used in ATMT experiments (e.g. [20, 24]). However, with $C$. acutatum, at this conidial concentration, the number of putative transformants growing in selection plates was too high and it was difficult to isolate discrete colonies (data not shown). Therefore, an experiment was carried out to test various parameters such as the concentration of the conidia, binary vector and the presence or absence of acetosyringone in the co-cultivation medium in order to develop an efficient protocol to reliably isolate individual transformants of $C$. acutatum. Results clearly showed that $10^{4}$ conidia per co-cultivation plate were optimal with an average transformation efficiency of between 45 and 156 transformants (Fig. 1). Even at $5 \times 10^{4}$ conidia per cocultivation plate, a large number of putative transformants appeared leading to coalescent colonies or a mycelial mat. Acetosyringone is a compound released by wounds in $A$. tumefaciens plant hosts in nature, which the bacterium uses as a signal for infection and T-DNA transfer [24] and its addition has been reported to increase the efficiency of ATMT [12]. However, with C. acutatum no substantial difference in the transformation efficiency was observed between the presence (IMAS) and absence (IM) of acetosyringone in the co-cultivation medium (Fig. 1). This suggests that acetosyringone added to the bacterial induction medium, prior to co-cultivation, was sufficient for the ATMT process. Co-cultivation of $C$. acutatum conidia and A. tumefaciens cells was routinely carried out at $22^{\circ} \mathrm{C}$. Experiments conducted at 20 and $25^{\circ} \mathrm{C}$, showed some degree of increased transformation efficiency at $25^{\circ} \mathrm{C}$ (results not shown). Further, pre-germination of conidia is frequently used prior to co-cultivation in fungal ATMT to increase the chances of infection and transformation of developing hyphal cells (e.g., [20]). In C. acutatum, pregermination of conidia is strictly required for direct transformation by electroporation [4]). However, in our ATMT experiments, incubation of conidia on co-cultivation plates for 24 or $48 \mathrm{~h}$ prior to the addition of bacterial cells did not improve the efficiency of transformation of $C$. acutatum. This in fact, decreased the efficiency of generating discrete colonies of transformants, presumably due to growth enhancement by pre-germination (data not shown). Interestingly, similar difficulties were observed with another Colletotrichum species, C. graminicola when the co-cultivation period was extended to 5 days [29]. Further, the A. tumefaciens strain AGL1 appears to be very efficient with various Colletotrichum spp. such as $C$. acutatum tested in this study, C. gloeosporioides (P. Ramos, pers. comm.) and C. graminicola [29].

In view of the polyphagus nature of $C$. acutatum and the existence of at least eight different phylogenetic groups namely A1-A8 [1], besides the transformation of isolate CA397, experiments were conducted to test the wider applicability of the method. Other $C$. acutatum isolates tested include PT29 (group A1 from white lupin), PT108, PT169 and PT227 (representing groups A2, A4 and A5, respectively, associated with olive anthracnose) and CR46 (group A3 from grapevine), which have been genetically characterised previously [1, 22, 23]. ATMT experiments with $C$. acutatum isolates PT29, PT108, PT169, PT227 and CR46 using AGL1 containing the binary vector pBHt2 yielded $\sim 120$ and $\sim 150$ transformants from $10^{4}$ conidia without and with acetosyringone in the induction medium, respectively. At least 25 transformants tested for each isolate showed stable hygromycin resistance. These results demonstrated that the ATMT technique developed might be used as an efficient tool for any C. acutatum isolate. All ATMT experiments were performed with appropriate controls. It is worth noting that, in the controls, after the co-cultivation period and transfer of the cellophane disc to selection plates only a diffuse background growth from the germinated spores was visible, but no clear colonies were formed. However, in areas where the cellophane disc was not in direct contact with the selection medium, such as ends of the membrane that were in contact with the side wall of the Petridish or over air bubbles that lifted the membrane above the selection medium, further mycelial growth was observable. This emphasises the importance of properly laying down the co-cultivation discs ensuring full contact with the selection medium including at the edges. Some of these colonies appearing in the control plate with the wild type isolate only grew slightly on PDA containing $250 \mu \mathrm{g} / \mathrm{ml}$ hygromycin, but not in YEG liquid medium containing an identical concentration of hygromycin, making this a better choice for effective selection of transformants. We routinely transfer putative transformants to sterile $1.5 \mathrm{ml}$ eppendorf tubes containing $1 \mathrm{ml} \mathrm{YEG}_{\mathrm{hyg}}$ before further subculture as necessary. This is a very useful method for avoiding any false positives as well as enabling the efficient management of hundreds of transformants, saving space as well as safe handling of each transformant avoiding any cross-contamination. The transformation frequency of 45-156 transformants per co-cultivation plate with $10^{4}$ conidia achieved in this work is clearly more efficient compared to previous reports of six transformants from $10^{7}$ conidia with $5 \mu \mathrm{g}$ DNA [4] and 0-17.9 per $\mu \mathrm{g}$ DNA using $10^{7}$ protoplasts [5]. Moreover, the protocol developed is also applicable to a wide range $C$. acutatum isolates from different host and genetic groups.

A collection of 20 randomly selected transformants (10 each from either IM or IMAS co-cultivation medium) was tested for mitotic stability of the transgene integration. This was carried out by three serial subcultures in non-selective medium, followed by transfer back to selection medium, 

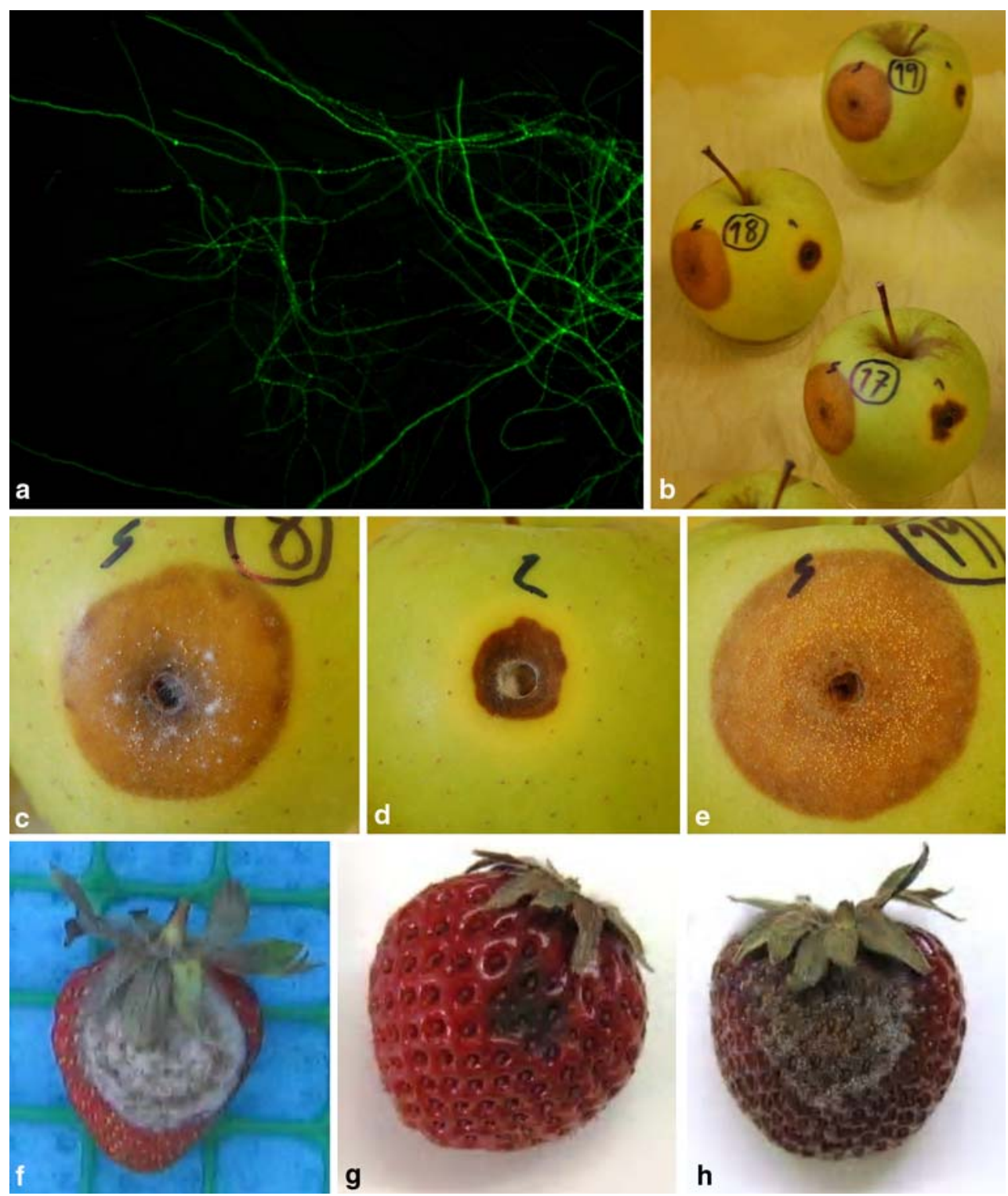

Fig. 3 (a) Hyphae of a Colletotrichum acutatum transformant generated with vector pBHt2-GFP expressing the green fluorescent protein visualised by epifluorescence microscopy $(400 \times)$. (b-h) Pathogenicity bioassay of $C$. acutatum insertional mutants generated by Agrobacterium tumefaciens-mediated transformation, showing disease reactions obtained after 13 -days incubation at $25^{\circ} \mathrm{C}$ under $100 \%$ relative humidity along with the wild type isolate CA397

where all 20 transformants grew in the presence of hygromycin. Further, epifluorescence microscopy of a selection of transformants obtained with binary vector pBHt2-GFP clearly showed $C$. acutatum hyphae expressing the GFP (Fig. 3). Hyphae of the wild type isolate or transformants produced with $\mathrm{pBHt} 2$ did not show any green fluorescence under the same conditions. GFP-tagged C. acutatum strains are likely to facilitate future epidemiological and host colonisation studies. (positive control). (b) Bioassay with apple fruits serves as a highthroughput screen, as 3-5 transformants can be tested on each fruit without interference from each other. (c-e) Symptoms obtained with the wild type (CA397), a low-pathogenicity mutant (1417) and a highpathogenicity mutant (1577), respectively, in screening bioassays on apple; (f-h) Symptoms obtained with the wild type (CA397), mutant 1417 and mutant 1577 , respectively, on strawberry fruits

A simple and quick DNA extraction method and a PCR assay were tested to verify the presence of transgenes in putative transformants, prior to Southern analysis or pathogenicity phenotype screening. Putative transformants were screened by PCR using specific primers for $h p h$ and $g f p$. Figure 1 shows an example of two sets of three transformants generated with vectors $\mathrm{pBHt} 2$ and $\mathrm{pBHt} 2-$ GFP, accompanied by the appropriate controls. Transformants obtained with vector pBHt2-GFP yielded $h p h$ and 


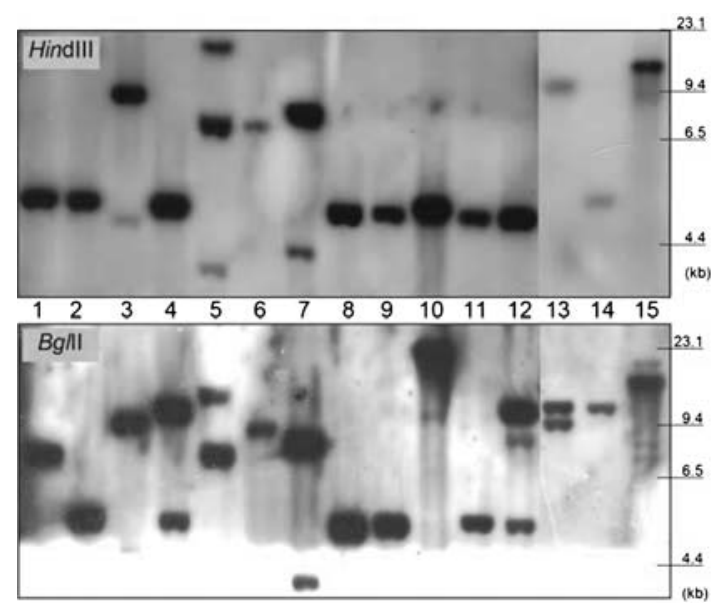

Fig. 4 Left (figure)-Southern analysis of T-DNA integration events in Colletotrichum acutatum transformants generated by Agrobacterium tumefaciens-mediated transformation; blots containing genomic DNA digested either with HindIII (single site within the T-DNA; top panel) or $B g I I I$ (no site within the T-DNA; bottom panel) were

gfp fragments of the expected sizes. Similarly, transformants obtained with $\mathrm{pBHt} 2$ yielded $h p h$ fragments but not gfp fragment. This rapid protocol provides a highthroughput PCR assay for the confirmation of $>100$ putative transformants per day.

Southern analysis of a selection of transformants using an $h p h$ gene probe was carried out to characterise the TDNA integration events in ATMT of $C$. acutatum. This was aimed at analysing single or multiple integrations as well as single copy or multi-copy integration of T-DNA at a location. For this experiment, transformants were chosen to represent the different variables tested, namely the type of binary vector ( $\mathrm{pBHt} 2$ or $\mathrm{pBHt} 2-\mathrm{GFP})$ and the presence (IMAS) or absence (IM) of acetosyringone in the co-cultivation medium. Genomic DNA from 36 transformants was digested with either $B g l I I$ (no restriction site in T-DNA) or HindIII (one restriction site in T-DNA outside of the probe region) and hybridised with the $h p h$ probe (Fig. 1). Transformants with single copy integration at a location should yield a single band with both the restriction enzymes and those with multiple integrations are expected to yield identical number of bands with the two enzymes. A multicopy (repeat) integration in a single location will yield a single band with $B g l I I$, expected to be at least twice the size of T-DNA ( $>10 \mathrm{~kb}$ for $\mathrm{pBHt} 2-\mathrm{GFP}$ and $>5.3 \mathrm{~kb}$ for $\mathrm{pBHt} 2$ ) and two bands with HindIII, one of which, representing the monomer, would be the same size as the T-DNA. Complex integrations such as both single copy and repeats in different locations in the same transformant would be more difficult to interpret, although this would be expected to result in more than one $B g l I I$ band of different sizes and a 'strong' HindIII band (corresponding to multiple monomers from the repeat) plus some 'weak' HindIII bands.
Southern analysis results based on the number and size of bands obtained with the two enzymes for each transformant revealed that single copy integration was most common (lanes 1, 2, 6, 8-11 and 14 in Fig. 4), representing $72.2 \%$ of the transformants analysed (Fig. 4). Up to four copies of T-DNA were detected in some examples representing 25\% multiple integrations (lanes 3-5, 7, 12, 13 and 15 in Fig. 4). A single case of multi-copy (T-DNA repeat) integration was detected (data not shown), with two HindIII bands and one $B g l I I$ band. In this transformant, the $B g l \mathrm{II}$ band was ca. $25 \mathrm{~kb}$ indicating the integration of a five-copy repeat of the T-DNA from vector pBHt2-GFP. The frequency of single copy integration obtained with ATMT of $C$. acutatum in this study is comparable to those reported with other Colletotrichum spp. such as $C$. trifolii [36] and C. lagenarium [19] and clearly higher than in $C$. graminicola [29]. Further, among the 36 transformants analysed, 27 were from the IMAS co-cultivation medium containing acetosyringone and nine were from IM without the inducer. Interestingly, the proportion of single copy integrations was similar (ca. 67\%) among these transformants, although acetosyringone has been reported to both increase [37] and decrease [38] the number of T-DNA integrations in different systems. Nearly $33 \%$ of the transformants yielded $B g l I I$ bands of a similar size (ca. $5.5 \mathrm{~kb}$ ), along with larger bands in some cases (e.g. lanes 2, 4, 8, 9, 11 and in Fig. 4). Considering that almost all of the 36 transformants analysed were from independent transformation experiments, the results suggests the possibility of integration hotspots in the $C$. acutatum genome. However, despite this, $66.7 \%$ of the transformants tested showed unique $B g l I I$ profiles. Based on this and the overall $72.2 \%$ single integration events, an estimated $48.2 \%$ of the 
C. acutatum transformants should contain a single copy random T-DNA integration in their genome.

Varied pathogenicity lifestyles of $C$. acutatum on different hosts as well as on different organs and cultivars of the same host are well recognised [2, 3, 39]. Discovery of pathogenicity genes in this key pathogen will enable further understanding of mechanisms driving the varied lifestyles. T-DNA-tagged mutants altered in pathogenicity offer an attractive approach for the identification of the genes. To analyse the pathogenicity phenotypes in a collection of nearly 1500 C. acutatum transformants, an applebased bioassay was used. Apples were preferred over strawberries, the original host of the wildtype isolate, because of easier availability throughout the year as well as the suitability to test multiple (six to eight) transformants on a single fruit and also due to less susceptibility to saprophytic invasion. The apple bioassay enabled the testing of 211 transformants in a single experiment. Most of the transformants caused extensive lesion or rot around the inoculation site comparable to the controls (Fig. 3). However, several transformants showed an altered pathogenicity phenotype including five that produced a very small lesion or no lesion and 16 were noted for enhanced severity (Figs. 3 and 5). The pathogen was reisolated from some of these lesions on selective medium and their identity [23] as well as the presence of the $h p h$ transgene was confirmed by PCR assays. These 21 transformants were reinoculated on apples in a second, fully replicated and randomly designed experiment and at least two were confirmed as low-pathogenicity mutants with no sporulation, slight or no mycelial formation and none to a very small lesion. Two other transformants were confirmed

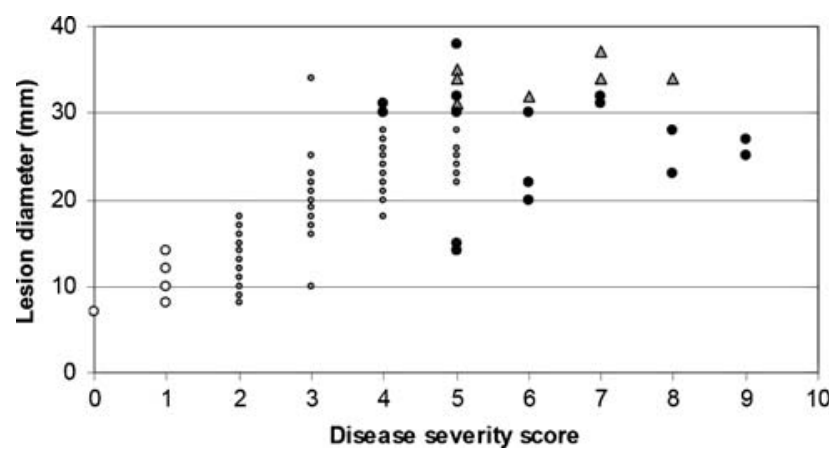

Fig. 5 Assessment of the pathogenicity phenotype of Colletotrichum acutatum transformants obtained by Agrobacterium tumefaciensmediated transformation, following inoculation on apples (incubated for 13 days at $25^{\circ} \mathrm{C}$ under $100 \%$ relative humidity). Distribution pattern of the disease severity score ( 0 , no lesion; 10 , large lesion with sporulation) and lesion diameter ( $\mathrm{mm}$ ) for the 211 transformants tested; five transformants displaying a lower level of infection (white circles) and 16 displaying a higher level of infection (black circles) compared to the controls (wild-type isolate CA397 and apple isolate AC58 shown in grey triangles) were selected for further screening; grey circles represent other transformants that were not tested further as high-pathogenicity mutants with abundant spore masses on the fruit surface, medium to high mycelial formation and a very large lesion area (data not shown). In pathogenicity bioassays on strawberries, insertional mutant 1417 showed markedly reduced level of infection with small areas of necrosis (Fig. 3g), compared to the wild type (Fig. 3f). This particular mutant showed a very similar phenotype in the initial screening using the apple bioassays (Fig. 3d). Mutant 1577 revealed heavy colonisation of the strawberry fruit and large area of necrosis with spore masses erupting (Fig. 3h), as with the apple bioassay (Fig. 3e). These results clearly demonstrate the value of the ATMT methodologies developed and the pathogenicity bioassays described for understanding the molecular mechanisms regulating varied infection processes in C. acutatum.

\section{Conclusions}

This is the first report of successful ATMT of C. acutatum, which is a wide host range cosmopolitan pathogen. The protocol described is clearly more efficient compared to the transformation methods reported for $C$. acutatum and offers various advantages. The transformation frequency of 45-156 per $10^{4}$ conidia is significantly higher than the 0-18 transformants per $\mu \mathrm{g}$ DNA reported for this species [4, 5]. Moreover, ATMT enables the transformation of conidia, instead of protoplasts, preparation of which is expensive and laborious, and also the lytic enzymes that often have batch variations. Efficiency of the ATMT of C. acutatum is comparable to that of various ascomycetes including C. graminicola [29] and higher than other Colletotrichum spp. such as C. trifolii [36], C. gloeosporioides [10], C. lagenarium [19] and C. higginsianum [40] where only one to three transformants per $10^{4}$ conidia were reported. We have also described a protocol that enables high-throughput PCR analysis of the $C$. acutatum transformants. Further, we have demonstrated that ATMT of $C$. acutatum leads to high levels $(>70 \%)$ of single integration events and this protocol can be used to rapidly generate a panel of T-DNA tagged pathogenicity mutants. PCR-based assays to recover the flanking sequences from T-DNA insertional mutants as well as T-DNA-based targeted gene knockout methods have recently been reported with various fungi (e.g. [18]). Thus, the ATMT of C. acutatum is a useful tool for gene discovery and gene function analysis to gain novel insights into the varied pathogenicity lifestyles exhibited by this economically important pathogen.

Acknowledgements This work was partly funded by FCT POCI 2010-FEDER (POCI/AGR/56321/2004 and SFRH/BPD/7161/2001, Portugal) and BBSRC (UK). The authors thank Dr. S. Kang 
(Pennsylvania State University, USA) for the pBHt2 plasmid and Dr. M. P. Challen, Dr. A. Soares and Ms. V. Odon (Warwick HRI) for providing bacterial strains, plasmids and protocols.

\section{References}

1. Sreenivasaprasad, S., \& Talhinhas, P. (2005). Genotypic and phenotypic diversity in Colletotrichum acutatum, a cosmopolitan pathogen causing anthracnose on a wide range of hosts. Molecular Plant Pathology, 6, 361-378.

2. Wharton, P. S., \& Schilder, A. C. (2007). Novel infection strategies of Colletotrichum acutatum on ripe blueberry fruit. Plant Pathology Doi:10.1111/j.365-3059.2007.01698.x

3. Wharton, P. S., \& Diéguez-Uribeondo, J. (2004). The biology of Colletotrichum acutatum. Anales del Jardín Botánico de Madrid, 61, 3-22.

4. Horowitz, S., Freeman, S., \& Sharon, A. (2002). Use of green fluorescent protein-transgenic strains to study pathogenic and nonpathogenic lifestyles in Colletotrichum acutatum. Phytopathology, 92, 743-749.

5. Chung, K. R., Shilts, T., Li, W., \& Timmer, L. W. (2002). Engineering a genetic transformation system for Colletotrichum acutatum, the causal fungus of lime anthracnose and postbloom fruit drop of citrus. FEMS Microbiology Letters, 213, 33-39.

6. Gelvin, S. B. (2003). Agrobacterium-mediated plant transformation: The biology behind the "gene-jockeying" tool. Microbiology and Molecular Biology Reviews, 67, 16-37.

7. McCullen, C. A., \& Binns, A. N. (2006). Agrobacterium tumefaciens and plant cell interactions and activities required for interkingdom macromolecular transfer. Annual Review of Cell and Developmental Biology, 22, 101-127.

8. Citovsky, V., Kozlovsky, S. V., Lacroix, B., Zaltsman, A., DafnyYelin, M., Vyas, S., Tovkach, A., \& Tzfira, T. (2007). Biological systems of the host cell involved in Agrobacterium infection. Cellular Microbiology, 9, 9-20.

9. Bundock, P., den Dulk-Ras, A., Beijersbergen, A., \& Hooykaas, P. J. J. (1995). Trans-kingdom T-DNA transfer from Agrobacterium tumefaciens to Saccharomyces cerevisiae. The EMBO Journal, 14, 3206-3214.

10. de Groot, M. J. A., Bundock, P., Hooykaas, P. J. J., \& Beijersbergen, A. G. M. (1998). Agrobacterium tumefaciens-mediated transformation of filamentous fungi. Nature Biotechnology, 16, 839-842.

11. Amey, R. C., Athey-Pollard, A., Burns, C., Mills, P. R., Bailey, A., \& Foster, G. D. (2002). PEG-mediated and Agrobacteriummediated transformation in the mycopathogen Verticillium fungicola. Mycological Research, 106, 4-11.

12. Michielse, C. B., Hooykaas, P. J. J., van den Hondel, C. A. M. J. J., \& Ram, A. F .J. (2005). Agrobacterium-mediated transformation as a tool for functional genomics in fungi. Current Genetics, 48, 1-17.

13. Lacroix, B., Tzfira, T., Vainstein, A., \& Citovsky, V. (2006). A case of promiscuity: Agrobacterium's endless hunt for new partners. Trends in Genetics, 22, 29-37.

14. Eckert, M., Maguire, K., Urban, M., Foster, S., Fitt, B., Lucas, J., \& Hammond-Kosack, K. (2005). Agrobacterium tumefaciensmediated transformation of Leptosphaeria spp. and Oeulimacula spp. with the reef coral gene DsRed and the jellyfish gene $g f p$. FEMS Microbiology Letters, 253, 67-74.

15. Müller, T., Benjdia, M., Avolio, M., Voigt, B., Menzel, D., Pardo, A., Frommer, W. B., Wipf, D. (2006). Functional expression of the green fluorescent protein in the ectomycorrhizal model fungus Hebeloma cylindrosporum. Mycorrhiza, $16,437-442$.
16. Zeilinger, S. (2004). Gene disruption in Trichoderma atroviride via Agrobacterium-mediated transformation. Current Genetics, $45,54-60$.

17. Sugui, J. A., Chang, Y. C., \& Kwon-Chung, K. J. (2005). Agrobacterium tumefaciens-mediated transformation of Aspergillus fumigatus: An efficient tool for insertional mutagenesis and targeted gene disruption. Applied and Environmental Microbiology, 71, 1798-1802.

18. Lee, M. H., \& Bostock, R. M. (2006). Agrobacterium T-DNAmediated integration and gene replacement in the brown rot pathogen Monilinia fructicola. Current Genetics, 49, 309-322.

19. Tsuji, G., Fujii, S., Fujihara, N., Hirose, C., Tsuge, S., Shiraishi, T., \& Kubo, Y. (2003). Agrobacterium tumefaciens-mediated transformation for random insertional mutagenesis in Colletotrichum lagenarium. Journal of General Plant Pathology, 69, 230 239.

20. Rogers, C. W., Challen, M. P., Green, J. R., \& Whipps, J. M. (2004). Use of REMI and Agrobacterium-mediated transformation to identify pathogenicity mutants of the biocontrol fungus, Coniothyrium minitans. FEMS Microbiology Letters, 241, $207-$ 214.

21. Sreenivasaprasad, S., Mills, P. R., Meehan, B. M., \& Brown, A. E. (1996). Phylogeny and systematics of 18 Colletotrichum species based on ribosomal DNA spacer sequences. Genome, 39, 499-512.

22. Talhinhas, P., Sreenivasaprasad, S., Neves-Martins, J., \& Oliveira, H. (2002). Genetic and morphological characterisation of Colletotrichum acutatum causing anthracnose of lupins. Phytopathology, 92, 986-996.

23. Talhinhas, P., Sreenivasaprasad, S., Neves-Martins, J., \& Oliveira, H. (2005). Molecular and phenotypic analyses reveal the association of diverse Colletotrichum acutatum groups and a low level of C. gloeosporioides with olive anthracnose. Applied and Environmental Microbiology, 71, 2987-2998.

24. Mullins, E. D., \& Kang, S. (2001). Transformation: A tool for studying fungal pathogens of plants. Cellular and Molecular Life Sciences, 58, 2043-2052.

25. Soares, A. X. (2004). Verticillium dahliae: Analysis of colonisation of strawberry cultivars (Fragaria $\times$ ananassa) \& development of a transformation tool for genetic manipulation, $\mathrm{PhD}$ Thesis, Imperial College, University of London, United Kingdom.

26. Mullins, E. D., Chen, X., Romaine, P., Raina, R., Geiser, D. M., \& Kang, S. (2001). Agrobacterium-mediated transformation of Fusarium oxysporum: An efficient tool for insertional mutagenesis and gene transfer. Phytopathology, 91, 173-190.

27. Hooykaas, P. J. J., Roobol, C., \& Schilperoort, R. A. (1979). Regulation of the transfer of Ti-plasmids of Agrobacterium tumefaciens. Journal of General Microbiology, 110, 99-109.

28. Reis, M. C., Fungaro, M. H. P., Duarte, R. T. D., Furlaneto, L., \& Furlaneto, M. C. (2004). Agrobacterium tumefaciens-mediated genetic transformation of the entomopathogenic fungus Beauveria bassiana. Journal of Microbiological Methods, 58, 197-202.

29. Flowers, J. L., \& Vaillancourt, L. J. (2005). Parameters affecting the efficiency of Agrobacterium tumefaciens-mediated transformation of Colletotrichum graminicola. Current Genetics, 48, 380-388.

30. Gregory, K. E. (2001). Transformation and transgene expression in homobasidiomycete mushrooms, $\mathrm{PhD}$ Thesis, Cranfield University, United Kingdom.

31. Sambrook, J., Fritsch, E. F., \& Maniatis, T. (1989). Molecular cloning: A laboratory manual (2nd ed). New York: Cold Spring Harbour Laboratory Press.

32. Burns, C., Leach, K. M., Elliott, T. J., Challen, M. P., Foster, G. D., \& Bailey, A. (2006). Evaluation of Agrobacterium-mediated transformation of Agaricus bisporus using a range of promoters 
linked to hygromycin resistance. Molecular Biotechnology, 32, 129-138.

33. Khang, C. H., Park, S.-Y., Lee, Y.-H., \& Kang, S. (2005). A dual selection based, targeted gene replacement tool for Magnaporthe grisea and Fusarium oxysporum. Fungal Genetics and Biology, 42, 483-492.

34. Weld, R. J., Eady, C. C., \& Ridgway, H. J. (2006). Agrobacterium-mediated transformation of Sclerotinia sclerotiorum. Journal of Microbiological Methods, 65, 202-207.

35. Betts, M. F., Tucker, S. L., Galadima, N., Meng, Y., Patel, G., Li, L., Donofrio, N., Floyd, A., Nolin, S., Brown, D., Mandel, M. A., Mitchell, T. K., Xu, J.-R., Dean, R. A., Farman, M. L., \& Orbach, M. J. (2007). Development of a high throughput transformation system for insertional mutagenesis in Magnaporthe oryzae. Fungal Genetics and Biology, 44, 1035-1049.

36. Takahara, H., Tsuji, G., Kubo, Y., Yamamoto, M., Toyoda, K., Inagaki, Y., Ichinose, Y., \& Shiraishi, T. (2004). Agrobacterium tumefaciens-mediated transformation as a tool for random mutagenesis of Colletotrichum trifolii. Journal of General Plant Pathology, 70, 93-96.

37. Rho, H. S., Kang, S., \& Lee, Y. H. (2001). Agrobacterium tumefaciens-mediated transformation of the plant pathogenic fungus, Magnaporthe grisea. Molecules and Cells, 12, 407-411.

38. Combier, J. P., Melayah, D., Raffier, C., Gay, G., \& Marmeisse, R. (2003). Agrobacterium tumefaciens-mediated transformation as a tool for insertional mutagenesis in the symbiotic ectomycorrhizal fungus Hebeloma cylindrosporum. FEMS Microbiology Letters, 220, 141-148.

39. Peres, N. A., Timmer, L. W., Adaskaveg, J. E., \& Correll, J. C. (2005). Lifestyles of Colletotrichum acutatum. Plant Disease, 89, 784-796.

40. O'Connell, R., Herbert, C., Sreenivasaprasad, S., Khatib, M., Esquerré-Tugayé, M. T., \& Dumas, B. (2004). A novel Arabidopsis-Colletotrichum pathosystem for the molecular dissection of plant-fungal interactions. Molecular Plant-Microbe Interactions, $17,272-282$ 